\title{
Bilge Karasu'nun Forum dergisinde yayımlanan sanat yazıları (1954-1959)
}

\section{Bora GÜRDAȘ 1}

APA: Gürdaş, B. (2020). Bilge Karasu'nun Forum dergisinde yayımlanan sanat yazıları (1954-1959). RumeliDE Dil ve Edebiyat Araşttrmaları Dergisi, (20), 296-309. DOI: 10.2900o/rumelide.791646.

\section{$\ddot{\mathbf{O z}}$}

Türkiye'de 1950’li yıllar Demokrat Parti'nin iktidara geldiği, Köy Enstitüleri ve Halkevleri gibi kurumların kapatıldı ̆̆ı, sanayi, inşaat ve tarıma önem verilen bir sürece işaret etmektedir. Bu dönemin sanat ortamında ise Devlet Güzel Sanatlar Akademisi’nin sürdürdüğü “akademik kübizm”, buna karşıt olarak gelişen "soyut sanat” ve bu yıllarda ivme kazanan göç olgusuna paralel olarak "köylü gerçekçiliği” öne çıkan eğilimlerdir. Aynı süreçte naif, otodidakt sanat ve "harika çocuk" kavramları da sanat ortamında yerini almıştır. 1954 yılında yayın hayatına başlayan, ağırlıklı olarak siyasi konulara yer veren, ülkenin siyasi gündeminde belirleyici rol oynayan Forum dergisinde yukarıda andığım konulara değinen kişi ise, yazın dünyamızda öykü, roman ve denemeleriyle bilinen Bilge Karasu'dur. Aynı yıl henüz 24 yaşında genç bir sanat eleştirmeni olarak Forum dergisine Ankara ve İstanbul'da gördüğü sergileri ve katıldığı etkinlikleri yazmaya başlayan Bilge Karasu 1954-1959 yılları arasında toplam 36 sanat eleştirisine imza atmıştır. Yazar, akademik resim eğitimi almaksızın resim yapmaya başlayan Cemil Eren, İhsan Cemal Karaburçak ve Hasan Kaptan gibi sanatçıların yanı sıra Ali Teoman Germaner, Sadi Diren, Bülent Arel, Nuri İyem, Şükriye Dikmen gibi isimlerin kişisel sergileri değerlendiren yazılar kaleme almıştır. Yazarın ayrıca dönemin sanat tartışmalarında son derece belirleyici olan Devlet Resim ve Heykel Sergileri, AICA (Uluslararası Sanat Eleştirmenleri Derneği) 5.Kongresi, İş ve İstihsal Sergisi gibi etkinlikler hakkında da yazıları mevcuttur. Bu çalışmada Bilge Karasu'nun ele aldı̆̆ı sanatçı, kavram, teknik, kurum ve tartışmalar, eleştirilerinde kullandığı terminoloji ve yöntem irdelenecektir. Bu doğrultuda 1950'lerin sanat ortamındaki temel konuların Bilge Karasu'nun sanat yazılarında nasıl ele alındı̆̆ı ortaya konulacaktır.

Anahtar kelimeler : 1950’lerde Türkiye, Bilge Karasu, Forum dergisi, Sanat eleştirisi

\section{Art articles by Bilge Karasu published in Forum magazine (1954-1959)}

\begin{abstract}
1950s in Turkey are noted as a period during which the Democrat Party came to power; institutions like Village Institutes and Halkevleri (community centers) were shut down; whereas industry, construction and agriculture were given particular importance. As for the period's art milieu, the "academic cubism" perpetuated by the State Academy of Fine Arts, the "abstract art" that emerged as an opposition thereof and the "folk realism" ensuing the phenomenon of migration which gained momentum during this era are the main artistic tendencies. Notions of naïve, autodidact art and "wunderkind" have accordingly been included in the artistic circles during the same period. It is Bilge Karasu, recognized for his stories, novels and essays in our literature, who has addressed the aforementioned topics in the Forum magazine which was founded in 1954; a magazine which covered mainly political issues, playing a determinant role in the political agenda of the country. A total of 36
\end{abstract}

Dr., Hacettepe Üniversitesi, Edebiyat Fakültesi, Sanat Tarihi Bölümü, Batı Sanatı ve Çağdaş Sanat ABD (Ankara, Türkiye), theeurotrash@gmail.com, ORCID ID: 0000-0002-6861-1823 [Makale kaylt tarihi: 01.01.2020-kabul tarihi: 22.01.2020; DOI: $10.29000 /$ rumelide.791646] 


\begin{abstract}
art critiques of Karasu has been published, who has started writing on the exhibitions and events he attended in Ankara and Istanbul for the Forum magazine the same year of its onset, at his tender age of 24 as a young art critic. Besides having written on artists who had no formal training such as Cemil Eren, İhsan Cemal Karaburçak and Hasan Kaptan, the author has penned the solo exhibitions of artists like Ali Teoman Germaner, Sadi Diren, Bülent Arel, Nuri İyem and Şükriye Dikmen. Karasu has also written on events that were eminently determinant for the art discussions of the period, such as the State Painting and Sculpture Exhibitions, 5th Congress of the AICA (International Association of Art Critics), and the İş ve İstihsal (Work and Production) Exhibition. In this essay, the artists, notions, techniques, institutions and discussions addressed by Karasu shall be examined along with the terminology and methodology the author has employed in his critiques. Accordingly, how the key issues of the art scene of 1950s have become apparent in art critiques of Karasu shall be put forth.
\end{abstract}

Keywords: Turkey in 1950s, Bilge Karasu, Forum magazine, art critique

\title{
Giriş
}

1950'lerde Türkiye'deki siyasi ve toplumsal dinamiklerde yaşanan değişim ve dönüşümler kültür ve sanat ortamı üzerinde etkili olmuştur. Demokrat Parti'nin (DP) Mayıs 1950 seçimlerinde ezici bir çoğunlukla iktidara geçişinin ardından bu sürece kadar Halkevleri ve Halkodaları ile sürdürülen kültürel kalkınma modelinin,yerini ekonomik kalkınmaya bıraktığı görülmektedir. 1951 yllında Demokrat Parti, Cumhuriyet Halk Parti'sinin (CHP) bir organı olarak görülen bu kurumları kapatmış ve mallarını hazineye devretmiştir. DP milletvekillerinin toplumsal özelliklerine bakıldığında Kemalist dönemdekilerden ayrılan birtakım yönler göze çarpmaktadır. CHP milletvekillerine göre DP milletvekilleri ortalama olarak daha gençtir, seçim bölgeleriyle çok daha köklü ilişkilere sahiptirler, üniversite eğitimi görmüş olan daha az, ticaret veya hukuk formasyonuna sahip olan çok daha fazladır. CHP ile olan en çarpıcı farklılık, bürokratik ve/veya askeri formasyona sahip milletvekillerinin hemen hemen olmayışıdır (Yasa Yaman, 1998 : 95 ; Zürcher, 2006 : 321).

Devletin kültür ve sanat olaylarını planlı olarak yönlendirdiği, sanatsız bir yapılanmayı düşünmediği 1923-1945 dönemi oluşumlarının aksine 1950 sonrasında DP hükümeti, bu tür bir program sunmamış, kültür/sanat devinimlerinin dışında kalmıştır. Devlet Resim ve Heykel Sergisi düzenlemenin dışında herhangi bir sanatsal etkinliğe katkı sağlamamıştır. Dolayısıyla bu süreçte devlet dışı oluşumların, kurumların sanat ve kültür alanına katkıları artmıştır. Örneğin İstanbul'da devlet galerisi yoktur ve sergilerin çoğu yabancı ülkelerin konsolosluk, haber merkezi ve kültür merkezi binalarında açılmaktadır. Sanat Sevenler Cemiyeti (Ankara, 1950), Sanat Dostları Derneği (İstanbul, 1951), Maya Sanat Galerisi (İstanbul, 1951), Helikon Sanat Derneği (Ankara, 1952), Ertem Galerisi (İstanbul, 1956), Milar Galerisi (Ankara, 1957) gibi oluşumlar bu yıllarda pek çok sergiye ev sahipliği yapmıştır (Yasa Yaman, $1998:$ 96, 98).

1950 sonrası sanat ortamında üç eğilimin öne çıktığı görülmektedir. Bu eğilimler, Devlet Güzel Sanatlar Akademisi'nin sürdürdüğü ve bu yıllarda kendini doğu-batı senteziyle tarif eden akademik kübizm, akademi eğitimine karşıt söylem geliştiren genç kuşak sanatçlların oluşturduğu soyut (non-figüratif) sanat ve köylü gerçekçiliği şeklinde sıralanabilir. Köylü gerçekçiliğinin uzantılarını akademik eğitim görmemiş, naif ve otodidakt sanatçıların ya da "harika çocuk"ların ortaya çıkışında izlemek mümkündür. Fakat Zeynep Yasa Yaman'a göre tüm bunları farklı açılardan bağlayan ve gündemi oluşturan ana söylem "soyut sanat” üzerine odaklanmaktadır (Yasa Yaman, 1998 : 100-101). 
Tüm bu tartışma konuları dönemin edebiyat, sanat ve siyaset üzerine başlıca süreli yayınları olan Yeditepe, Beş Sanat, Varlk, Dost ve Forum dergilerinde, Ulus ve Vatan gibi gazetelerde kendine yer bulmuştur. Söz konusu yayınlardan Forum dergisi, 1 Nisan 1954 tarihini taşıyan ilk sayısından itibaren on beş günde bir yayımlanan, 1968 yllına kadar faaliyet göstermişse de Türk siyasi ve düşünce hayatında 27 Mayıs 1960’a kadar sürdürdüğü çizgisiyle yer etmiş bir dergidir. Derginin çekirdek kadrosunu, 1940'ların sonlarında eğitim amacıyla yurt dışına giden ve 1950'lerin başlarında yurda dönerek büyük kısmı Siyasal Bilgiler Fakültesi’nde göreve başlayan akademisyenler oluşturmaktadır (Dede, 2015 : 451, 454). Derginin çıkışındaki isimler ile yazar kadrosuna sonradan katılan kişiler arasında şunlar sayılabilir: başta Aydın Yalçın olmak üzere, Bülent Ecevit, Cavid Erginsoy, Bedi Feyzioğlu, Mukbil Özyörük, Nilüfer Yalçın, Turhan Feyzioğlu, Turan Güneş, Osman Okyar, Ziya Müezzinoğlu, Yaşar Karayalçın, Kudret Ayiter, Bahri Savcı, Akif Erginay, Cahit Talas, Muammer Aksoy, Mümtaz Sosyal, Şerif Mardin, Coşkun Kırca, Nejat Bengül, Necat Erder, Metin And ve İsmail Türk (Çakmak, 2007 : 40).

Forum'da, başyazı ve on beş günün notları dışında; kapsamlı araştırmaların yer aldığı 'İncelemeler', aralarında makale değerinde yazıların yer aldı̆̆ 'Okurların Forumu', yabancı yayınlardan çıkan bazı çevirilerin yer aldığı 'Ne diyorlar?' kısımları ile 'Kültür ve Sanat' bölümü de bulunmaktadır (Çakmak, 2007 : 47). Bu sayfalarda İlhan Mimaroğlu, Bedii Sevin, Turgut Uyar, Güner Sümer, Hüseyin Cöntürk, Metin And, Bülent Ecevit, Gültekin Oransay, Kaya Özsezgin ve Bilge Karasu gibi yazarların müzik, opera, tiyatro, edebiyat ve plastik sanatlar hakkındaki yazılarına yer verilmiştir. Çalışmamızın konusunu oluşturan Bilge Karasu, derginin kültür ve sanat sayfalarına edebiyat yazılarının ve öykülerinin yanı sıra ağırlıklı olarak resim ve heykel eleştirileriyle katkıda bulunmuştur² ${ }^{2}$

Yazarın Forum dergisinde, otodidakt sanat, harika çocuk olgusu ve pek çok kişisel serginin yanı sıra dönemin sanat tartışmalarında son derece belirleyici olan Uluslararası Sanat Eleştirmenleri Derneği (AICA) 5.Kongresi, İş ve İstihsal Sergisi ve Devlet Resim ve Heykel sergileri hakkında yazıları yayımlanmıştır. Bu çalışmada Karasu'nun eleştirel üslubu, söz konusu kavram, kurum, etkinlik ve sanatçllar ekseninde gruplandırılarak incelenecektir.

\section{Devlet resim ve heykel sergileri}

Bilge Karasu'nun, hakkında toplam 4 eleştiri yazdığı Devlet Resim ve Heykel Sergileri’nin ilki 29 Ekim 1939 tarihinde gerçekleştirilmiş, hem grup etkinliklerini hem de bireysel çalışmaları bünyesinde toplamıştır. Ankara'da açlldıktan sonra 1954'ten itibaren İstanbul ve bazen Eskişehir, Bursa ve İzmir'e taşınan yıllık Devlet Resim ve Heykel Sergileri, sanatçıların ödüllendirildikleri ve belli sayıda yapıtların resmi dairelere konmak üzere devlet tarafından satın alındığı bir etkinliktir. Profesyonel veya amatör tüm katılımcıların yapıtlarının sergilendiği etkinlikte seçici kurul her yıl ya da iki yılda bir değişmekte, ama genellikle dönüşümlü olarak aynı isimlere rastlanmaktadır. Devlet Resim ve Heykel Sergileri, başlangıcından itibaren pek çok tartışmaya konu olmuş, sergilenen eserler biçim ve içerik yönünden eleştirilmiş, jürinin seçimi tartışılmıştır.

Etkinliğin 1950’lerdeki görüntüsüne baktığımızda hoşnutsuz görüşlerin yavaş yavaş belirmeye başladığı gözlemlenmektedir. 15 Nisan 1950 tarihinde açılan 11. Devlet Resim ve Heykel Sergisi o güne dek

Şişli Terakki Lisesi'nde ve İstanbul Üniversitesi Edebiyat Fakültesi Felsefe Bölümü'nde okuyan Bilge Karasu, Basın-Yayın ve Turizm Genel Müdürlüğü'nde, Ankara Radyosu Dıș Yayınlar Bölümü'nde çalıșmıștır. 1963-64'te Rockefeller Bursu'yla Avrupa'nın çeşitli ülkelerinde bulunan yazar, 1974'te Hacettepe Üniversitesi'nde öğretim görevlisi olarak çalışmaya başlamıştır. İlk yazısı 1950'de, ilk öyküsü de 1952'de Seçilmiş Hikâyeler Dergisi'nde yayımlanan Bilge Karasu, 1963 yılında D. H. Lawrence'ın The Man Who Died (Ölen Adam) kitabının çevirisiyle Türk Dil Kurumu Çeviri Odülü'nü, 1971'de Uzun Sürmüş Bir Günün Akşamı kitabıyla Sait Faik Hikâye Armağanı'nı, 1991'de Gece kitabı ile Pegasus Ödülü'nü ve 1994'te Ne Kitapsız Ne Kedisiz'le Sedat Simavi Vakfı Edebiyat Ödülü'nü almıştır (https://www.metiskitap.com/catalog/author/796).

Address

Kurklareli University, Faculty of Arts and Sciences, Department of Turkish Language and Literature, Kayalı Campus-Kırklareli/TURKEY e-mail: editor@rumelide.com 
düzenlenen devlet sergileri içinde en iyilerinden biri olarak değerlendirilmiştir. Sergideki yapitların yeniliklere açı, dünyadaki çağdaş akımlarla paralelliği Türk resmi açısından olumlu bulunmuştur. Ancak bunu takip eden 12. ve 13. sergiler hayal kırıklığı yaratmıştır (Kaygısız Ergin, 2000 : 65-66). Nurullah Berk, "1952 sergisinin de diğerleri gibi hiçbir gelişme ve yükselme kaydetmediğini, amatörlerin cesaretlenerek istila ettikleri Devlet Sergilerinin, üçüncü sınıf basma kalıp eserleri bir araya toplayan bir amatörler sergisine dönüştüğünü” belirtmiştir (Berk, 1952 : 2). 15 Nisan 1953’te açllan 14. sergi eserler ve mekân arasındaki uyumsuzluklarla, 15 Nisan 1954’te açlan 15. sergi ise etkinliğge kabul edilen heykel sayısının azlığıyla dikkat çekmiştir (Kaygısız Ergin, $2000: 67-68$ ).

Bilge Karasu, 15. Devlet Resim ve Heykel Sergisi hakkında kaleme aldığı eleştirisinde etkinliğe katılan heykellerin hem nitel hem nicel yönden zayıf olduğuna vurgu yapar:

"Kataloğa 242 resim, 6 heykel yazılmış. Heykeller, üzerlerinde durulacak şeyler olmaktan uzak (...) Yurtta heykeltraş da var, heykel yapan da var. Bunların eserleri sergiye neden girmemiş diye düşünmekten alamıyorsunuz kendinizi (...) Sanatçıların sergiye katılmadıkları düşünülebilir. Neden katılmamışlar, onu düşünmeyelim ama ya o 6 heykelin \%90’ı kötü olunca...” (Karasu, 1954b : 15).

Sergiye katılan ressamlardan Cemal Bingöl, Adnan Çoker, Bedri Rahmi Eyüboğlu, Eren Eyüboğlu ve Cemal Tollu gibi isimlerin üretimlerini genel toplam içinde başarılı bulan yazar, sergiye seçilen eserlerin çoğunun "yeniliğe" kapalı oluşuna ve üslup ile tekrara düşme arasındaki ayrıma değinir:

\begin{abstract}
"Resimlerin karşısında insan üzülüyor. 91 ressam katılmış sergiye. Ama pek çoğunda sanatçının temel ırası olacak yeni yeni denemelere girişme, yapmış olduğu ile yetinmeme, kısaca, geveleme yerine eser verme gücü görülmüyor. Bu eski-yeni, genç-yaşlı karşıtlığı değil, bambaşka bir sorav. Üslubu olmak, bir temel üsluba bağlı kalarak eser vermekle, kendini tekrar edip durmak bambaşka şeyler. Üslup bir görüş, bir kavrayış oldukça, değişik eserlerin verilmesine engel olmaz ama yalnızca birtakım “teknikler, truc”lerle ayakta tutulmağa çalışılıyorsa, üslup üslupluktan, eser eserlikten çıkar” (Karasu, 1954b : 15).
\end{abstract}

Yazar, 1956 yllında düzenlenen 17. serginin ise "orta bir düzeyin üstüne yükselen resimlerin çokluğuyla dikkat çektiğini” belirtir. Karasu'nun bu sergiye olumlu yaklaştığı temel nokta, farklı resim türlerinin farklı kesimler tarafından ortaya konan örneklerine yer verilmesi ve soyut resimlerin sayısının artmış olmasidır:

\begin{abstract}
"Sergide ilk göze çarpan şey, eskiden beri sürüp gelen birtakım kalıpların kırılmış olduğu. Örneğin "Manzara" adı verilen resimler eskiden, daha çok değerleriyle ölçüleri katılaşmış ressamların eserleri arasında görülürdü. Bu yıl gerek "Manzara”lar, gerekse "Natürmort”lar genç, yaşlı birçok ressamlarda görüldüğü gibi, eskiden yalnız "Manzara"larla uğraşan birtakım ressamların "Portre"lere, "Genre" sahnelerine yöneldikleri görülüyor. Öte yandan soyut resimler, non-figüratif'ler yalnızca birkaç gencin yahut bu yeni yolla ilgilenen daha yaşlı ressamların işi olmaktan çıkmış, genel bir eğinme haline gelmiş (...)" (Karasu, 1956c : 28).
\end{abstract}

Ancak bu sergiye katılan heykellerden memnun olmayan yazar, "Zühtü Müridoğlu'nun kendini tekrar ettiğini, İlhan Koman'ın zayıf bir eser verdiğini, Şadi Çalık’ın heykelinin durukluğunu, hareketsizliğini seyircisine de aşıladığını, Kuzgun Acar'ın ikisi boyalı tahta, biri tel, biri de kemik, dört heykelinde kendini denemenin, tesadüfün elinden kurtaramamış gibi olduğunu" düşünmektedir (Karasu, 1956c : 29).

Bilge Karasu, 18. Sergi için kaleme aldığı eleştirisine ise "sergileyişten yakındığım sanılmasın, bu kez sergiden yakınacağım” sözleriyle başlar ve 1954 yılında dile getirdiği bazı sorunların tekrarlandığına işaret eder: 
"Devlet sergisi elbette apayrı birtakım anlayışları yanyana getirecektir. Elbette genç ressamların gitgide çoğalmasından ötürü 30 yıl, 40 yıl öncesinin havasından gitgide sıyrılacaktır. Ancak resimlerin - eski anlayışla yapılmış olsun, yeni anlayışla yapılmış olsun- kabak tadı verenlerini bir araya getirmeye - handiyse çabalaması diyeceğim- de hakkı olmasa gerek. Devlet sergisi her yıl daha çabuk gezilen bir sergi haline geliyor, insan - birtakım adları boşuna arıyor da demiyeceğim, sergideki resimler üzerinde durmağa çalışalım- bir heyecan, bir çarpıcılık arıyor, bulamıyor" (Karasu, 1957f : 23).

Yazar bu ve ertesi yıl düzenlenen sergide de heykellere yönelik eleştirisini sürdürmüştür. 1 Mayıs 1958 tarihinde Dil ve Tarih-Coğrafya Fakültesi'nde açılan 19. Devlet Resim ve Heykel Sergisi'ni “heykelin artık bir dert halini aldığını gösteren" bir etkinlik olarak tanımlayan Karasu, "serginin adının "Resim ve Heykel” sergisi olmasının, heykelin kötü örneklerle "teşvik” edilmesini gerektirmediğini” vurgulamıştır (Karasu, 1958d : 22).

\section{Harika çocuk olgusu}

Bilge Karasu'nun hakkında yazdığı bir başka konu olan Türkiye'de "harika çocuk" olgusu, ilk olarak 1940’lı yllarda müzik alanında ardından 1950’lerde plastik sanatlar alanında görülmektedir. İlki 1948'de, ikincisi 1956'da çıkarılan kanunlarla, sanat alanında başarı gösteren çocukların eğitimini sağlamak amaçlanmıştır. Bu konuda ilk adımlar 1945 yllında İsmet İnönü’nün gittiği bir resitalde 3-4 yaşlarındaki İdil Biret'i dinlemesiyle atılmıştır. Yasanın çıkması ise 1948 yılı Temmuz ayında gerçekleşmiştir. “İdil - Suna Kanunu” olarak da bilinen, “İdil Biret ve Suna Kan’ın yabancı memleketlere müzik tahsiline gönderilmesine dair kanun” mecliste onaylanır (Kahramankaptan, 1998 : 96 - 102).

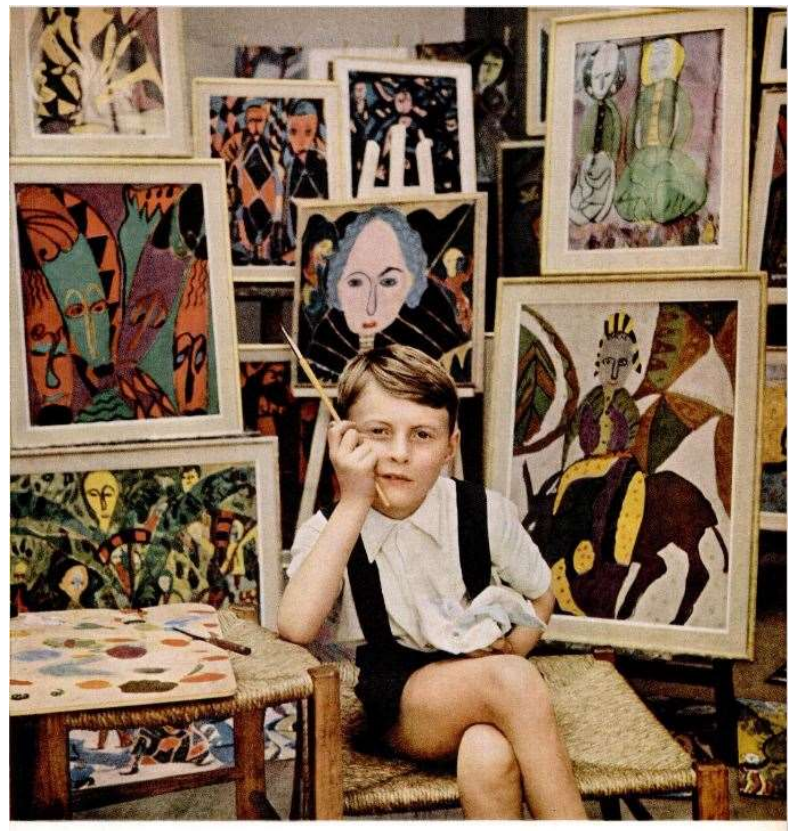

Young Man of Modern Art

A 10-YFAR-OLD PAINTER IS TURKISH DELIGHT OF THE ART WORLD

Tablo 1 : Hasan Kaptan Life Magazine'de (Anonim, 1952 : 85).

1950 yılında ilk sergisini açan, sanatçı Arif Kaptan'ın oğlu Hasan Kaptan’ın çalışmaları da sanat camiasının dikkatini çekmiştir. Kaptan'ın kısa sürede hem Ankara hem İstanbul'da açtığı sergiler "harika çocuk" olarak nitelenmesini sağlamış, yurtdışı bursunu gündeme getirmiştir; Hasan Kaptan,1951 ve 1952 yıllarında Fransa ve Amerika'da açtığı sergilerle yabancı basının da ilgisini çekmiş 
ve 1956 yllındaki "Güzel sanatlarda fevkalade istidat gösteren çocukların devlet tarafından yetiştirilmesi hakkındaki kanun” ile Paris’e gönderilmiştir (Elvan Erturan, 2001 : 62 - 63).

Yerli basında ise Hasan Kaptan’ın ilk sergisinden itibaren pek çok yazı yayınlanmış, Bedri Rahmi Eyüboğlu, İbrahim Çallı, Necdet Evliyagil, Halim Yağcıŏ̆lu, İhsan Cemal Karaburçak ve Bülent Ecevit gibi isimler, genç ressamın üretimlerinden övgüyle söz etmişlerdir. Halim Yağcıŏ̆lu sanatçının Helikon Galerisi’nde açılan bir sergisi üzerine şunları söylemektedir:

“Helikon'da bu istidatlı çocuğun son sergisini gördük. Tabloların yarısından fazlası satılmıştı. Tek resim satamayan ressamlarımız bu başarıya ne derler bilemeyiz. Çocuğun renk anlayışı ve o renklerle ortaya getirdiği armonide aramalı bu sırrı bu başarıyı her halde diyoruz. Bu sefer kafalara fazla vurulmuş küçük kaptan. Hep üç kafalar. Ama güzel. Çekici. Derinlik hakkında da bir şeyler öğrenmiş. Gelecekte Hasan Kaptan'la milletimizin övüneceğini umuyoruz. Viva Hasan Kaptan” (Yağcığlu,1954 :156-157).

Bülent Ecevit ise Hasan Kaptan’ın salt bir “çocuk ressam” olarak değerlendirilmesini doğru bulmadığını şu sözlerle ifade eder :

\begin{abstract}
"Son zamanlarda çocukların resim eğitimine yeni bir anlayış getirilmekle, dünyanın birçok yerlerinde çocuk resmi diye bir tarz ortaya çıkmıştır. Hasan Kaptan'ın resimleri bu tarza uymamaktadır. Hattâ, Hasan Kaptan'ın resimleri, çocuk resmindeki saflı̆̆a özenen ergin ressamların tarzlarına da uymamaktadır(...) Artık bir sanat tenkidçisine düşen, Hasan Kaptan'ı bir ressam olarak tenkid etmektir. Hasan Kaptan adında bir ressam yerine, resme «istidatlı» bir çocuktan bahsetmekte hâlâ ısrar eden tenkidciler, Hasan Kaptan'ın resimlerini neden çocuk resmi saydıklarını da açıklamayı ihmal etmeseler, yazıları, belki ciddiye alınabilir" (Ecevit, $1954: 3$ ).
\end{abstract}

Bilge Karasu, Ecevit’in temenni ettiği gibi Hasan Kaptan’ın (sadece yaşını belirtir) resimlerini “çocuk ressam” algısından bağımsız, bir "ressam” olarak sanatsal çizgisindeki değişimleri yönünden ele alır:

“(...) Hasan Kaptan tek tek yüzlere yer verdiği resimlerini geride bırakmış. Resimlerinin çoğu insan birikintisi (...) Bir iki manzarasını, renkli bir boşluk içinde yüzen balıklarını bir yana bırakırsak bir yüz kalabalığı, bir göz dünyası içinde kalırız" (Karasu, 1954a : 18).

Yazar, diğer sanat eleştirilerinde de görülebileceği gibi sıklıkla formalist (biçimci) bir üslubu benimseyerek, sanat yapıtlarını renk, ışık, istif gibi değerler üzerinden incelemektedir:

“(...) Atların, balıkların girdiği resimler, istif bakımından daha yalın. (...) Renklendirme gücü öteden beri bilinen Hasan Kaptan'ın bu resimlerinde renklerin biraz koyulaşıp karardığı, parlak renklerin eskisi kadar çok kullanılmadığı görülüyor. (...) Balıklar, bir nakış düzeni içinde” (Karasu, 1954a : 18).

Öte yandan gencecik bir ressamın yaşamında karşılaşacağı olası güçlükleri yine Kaptan’ın bu sergisinde ele aldığı temalara atıfta bulunarak değerlendiren yazar " Hasan Kaptan, dünyayı tanıma yolunda yeni bir döneme girdi sanıyorum. Duygusal davranışı, insanların acılarına yönelmiş. Bu dünya artık onun için de rahat bir dünya değil. Bakan gözler, kötü kişiler var...” der (Karasu, 1954a : 18).

Karasu, Helikon Sanat Derneğı”nin 25 Şubat 1956 tarihinde Türk-Amerikan Derneği’nde açttğ̆ “Modern Türk Resim Sergisi” vesilesiyle tekrar Hasan Kaptan’a değinir. Karasu, ressamın söz konusu sergide yer alan eserlerindeki üslup değişimine dikkat çekerek "gerek insansız resim yapmakta olduğunu gerekse de bu yeni döneminde eşyanın da resmin de daha derinde olan bir duyarlığını edinme yolunda olduğunu gösterdiğini” ifade eder (Karasu, 1956a : 21). 


\section{Otodidakt sanat}

Yazarın akademik anlamda resim eğitimi almamış "yetişkin" sanatçllara da yazılarında yer verdiği ve büyük ölçüde desteklediği görülmektedir. Otodidakt (sanat eğitimi almamış ve kendi kendini yetiştirmiş) ressamlar 1950'lerde ilgi görmeye başlamış, Nuri Özgiray, Hakkı Öcal, Yüksel Arslan, İhsan Cemal Karaburçak ve Cemil Eren gibi isimler bu süreçte pek çok sergi açmıştır. Bu yılların öne çıan otodidakt sanatçlarından İhsan Cemal Karaburçak’n Ankara'da açtı̆̆ı sergiler, basında öncelikle sanatçının 50 yaşında resme başlamış olması sebebiyle ilgi çekici bulunmuştur. Özellikle peyzaj ve portre çalışmalarına yoğunlaşan sanatçı, 1956 yllında açtığı sergide soyut resimler de sergilemiştir. Resimleri dönemin önemli yazar ve eleştirmenleri arasında yer alan Zahir Güvemli, Bülent Ecevit, Kaya Özsezgin ve Bilge Karasu gibi isimlerin dikkatini çekmiştir (Elvan Erturan, 2001 : 118 - 119).

Karasu sanatçının 1955 yılında Sanatseverler Kulübü’nde (Ankara) açttğı sergisine dair kaleme aldığı yazısında öncelikle sergi salonunun fiziksel koşullarının yetersizliğini ve sergileme modelini eleştirir. Ardından Karaburçak'ın sanatsal gelişim ve değişim çizgisine vurgu yapar:

“(...) Aralarında ressamın bundan 10-11 yıl önce nasıl çalıştı̆̆ını göstermek için konmuş olan resimler de vardı. Soğuk renklerinden, akçıl biçimlerinden uzaklaşmış olan Karaburçak, bir buçuk yıl içinde yaptığı resimlerde büyük bir çeşitlilik gösteriyor. Biraz daha eski olanlarında kırmızı, turuncu renklerin üstünlüğüne karşılık yenilerinde mavilerin, yeşillerin değeri daha büyük” (Karasu, 1955e : 22).

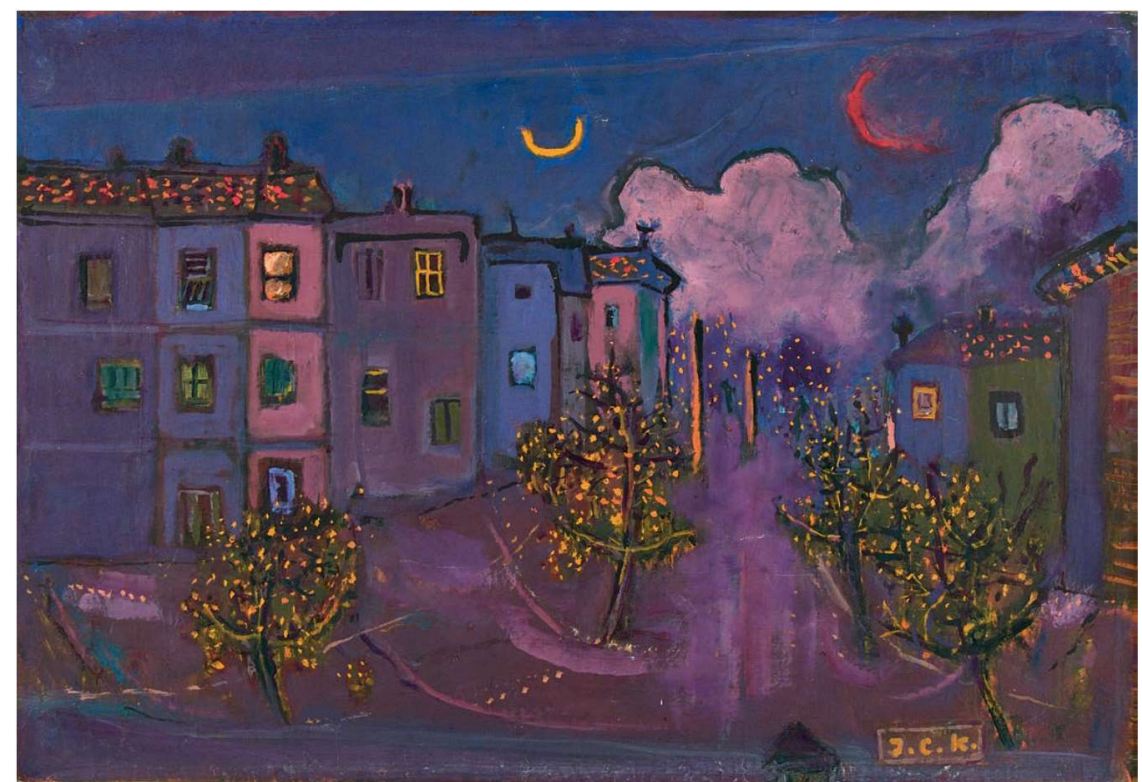

Tablo 2 : İhsan Cemal Karaburçak, "Yenişehir'de Gece”, 1952-1970, Duralit üzerine yağliboya, 45x65 cm. Ahu\&Can Has Koleksiyonu (Akkoyunlu Ersöz, B. ve Bahar, T, 2011 : s. 87).

Öte yandan yazar, sanatçının resimlerindeki biçim ve içerik ilişkisini konu dağarcığı ile renk ve çizgi değerleri üzerinden ele alır:

"Karaburçak her şeyden önce doğayı çok seven, bir ağacı, bir evi, bir sokağı çok iyi değerlendirmesini bilen bir ressam. Renkleri, durgun biçimleri, tablolarının çoğundaki enine bölünme, resimlerine duygu dolu bir ifade veriyor. Ressamın o sessiz, dingin, renk içindeki evleri, ağaçları, bahçeleri nasıl sevdiğini anlıyoruz (...) Sonra evlerin içine giriyoruz. Pencereden özlemle bakan kadınlar, kızlar; sıcak oda köşeleri...Pencereden bakanlar, incelmiş çizgiler, hafiflemiş renklerle veriliyor" (Karasu, 1955e : 22-23). 
Ressam Eşref Üren'in yönlendirmeleriyle çalışmalarına başlayan Cemil Eren de otodidakt sanatçılardandır. 1950'li yılların ortalarında değişik malzemeleri bir araya getirerek çalışmaya başlayan sanatçı boya, çakıl taşı, midye kabuğu gibi farklı malzemeleri kullanarak kolaj çalışmaları yapar. 1956 yılında tasarladığı ve renklerini belirlediği üç dokuma halılar ile denemelerine devam etmiştir. 1957 yılında açtığı ilk sergisinde kolajlar, soyut resimler ve halılar bir arada sergilenmiştir (Elvan Erturan, 2001 : 103 - 104). Eren'in Avrupa'ya gitmemiş, akademik eğitim almamış olmasına karşın "çağdaş nonfigüratif sanat ile at başı yürümesi, - sık sık Avrupa'ya giden, İstanbul'un sanat çevreleri içinde doğup büyüyen ama post-empresyonizm ve ekspresyonizm'den ileri gidemediği düşünülen sanatçılarla karşılaştırıldığında- modern akımlarla sarmaş dolaş oluşu” şaşırtıcı bulunmuş ve övgüyle karşılanmıştır (Güran, $1958: 4$ ).

Cemil Eren’in Türk-Amerikan Derneği’nde açllan ilk sergisini kaleme alan Karasu da benzer biçimde, sanatçının hem non-figüratif resimlerini hem de üç boyutlu malzemeler kullanarak ürettiği işlerini başarılı bulmuştur:

\begin{abstract}
"Ressam gene non-figüratif yolda yürümüştür, gene yüzeye bağlı kalmıștır ama artık birtakım çizgiler çıkmıştır ortaya: Devinen çizgiler. Bu çizgilerin ardında birtakım parlak lekeler var, böylece resim yüzeye bağlı kalmaktan kurtulmaya doğru gitmeye başlıyor. Bir şeylerin geleceğini sezinliyorsunuz. O şey ilk olarak birtakım tarak dişleri, bakır yüzeyler, düğmeler, toplu iğne demetleri halinde karşımıza çıkıyor (...) Ancak bir ötesi, bunların yanına birtakım deniz hayvanlarının kavkılarını da getiriyor" (Karasu, 1957b : 22-23).
\end{abstract}

Karasu, sanatçının gelişim çizgisini takip eder ve 1958 yılında Türk-Amerikan Derneği'nde açılan sergisi için yazdığı eleştiride Eren’in mozaik uygulamalarının yanı sıra resimlerindeki kompozisyon ve renk algısının çeşitlendiğine dikkat çeker:

\begin{abstract}
“(...) Bir yahut birkaç çizgiyi kalın çizip dik açılar yaptıra yaptıra dolaştırmak, meydana gelen irili ufaklı dörtgenlerin renklendirilmesi ile bir çeşit mozaik etkisi uyandırmak bir oyun olmaktan öteye geçmeyebilirdi ama bu sınılayıcı, durdurucu, polis-çizginin içinde kalan dörtgenlerin oranları, yığılışları, istifleri, renklendirilmesi Eren'in gelişmesini izleyenler için, beklenilmeyen bir etki taşıyordu. Katıksız, canlı, korkusuz maviler, sarılar, turuncular, yeşillerle allar bambaşka bir Eren’i muştuladı" (Karasu, 1958a : 24).
\end{abstract}

Eren’in sanatını her sergisinde giderek olgunlaştırdığını düşünen yazar, sanatçının malzeme ve teknik arayışlarını olumlamaktadır. 1959 tarihli "Yeni Eren" başlıklı yazısında sanatçının resimlerinde görülmeye başlanan ışık algısını anakronik bir biçimde "Barok ışık” olarak tanımlar :

“(...) Türk-Amerikan Derneği'nde açtığı yeni sergiyle, Eren, gelişiminin belki en zevkli, en tatlı noktasında görünüyor. Geçen sergisinden bu yana epey yol almış (...) Eren’in sergisi üzerine söylenen sözlerde ortak bir yön, "bu resimlerde ışık olduğu"dur (...) Eren’in başardığı, bir çeşit "Baroque resim ışı̆̆ı" bulmuş olmaktadır. Düzlemin içeriye doğru delinmesi yanılsaması, ufak ufak planların - genel bir aydınlanma içinde- düzenli bir aydınlık kertelemesine uyması, biçimlerin ışık içinde "erimesi” bir yana, "Baroque" resmin arkasındaki gizemsel bir duygu-düşünce yapısına yakın bir duygu dünyası sezilmesi bakımından da, bu “Baroque'a yakınlı" üzerinde durulabilir” (Karasu, 1959b : 22).

\title{
AICA (Uluslararası Sanat Eleştirmenleri Derneği) ve "İş ve İstihsal” Yarışması
}

Ağırlıklı olarak Ankara'da düzenlenen sanat etkinliklerini takip ederek Forum dergisine yazan Karasu, bu süreçte İstanbul'un sanat ortamında olup bitenlere de uzak kalmamıştır. Dönemin sanat tartışmalarında önemli yer tutan, sanatçı, akademisyen ve eleştirmenleri kutuplaştıran, 1954 yılında İstanbul'da gerçekleştirilen AICA 5. Kongresi ve eş zamanlı olarak düzenlenen "İş ve İstihsal” yarışması yazarın ele aldığı konulardan biri olmuştur. 
1940'lı yılların sonlarına doğru sanat dünyasının hareket kazanması, yeni ekollerin ortaya çıması ve yeni sanat okullarının açılması sanat dünyasında yeni bir tartışma ortamı yaratmıştır. Dönemin önemli sanat eleştirmenleri, sanat tarihçileri, sanat eğitimcileri ve küratörlerinin de katılımı ile UNESCO Genel Merkezi'nde bu nedenle 1948 ve 1949 yllarında iki kongre düzenlenmiştir. Amaçları sanat eleştirmenliği mesleğine dair gelişen farklı bakış açılarını karşılaştırmak, sanatçılara/kamuya karşı sorumlulukları analiz etmek ve sanat tarihi alanındaki gelişmelere sanat eleştirmenliğinin katkısını belirlemektir. Dünya çapında toplanan sanat eleştirmenleri arasında André Chastel, Jorge Crespo de la Serna, Pierre Courthion, Charles Estienne, Chou Ling, Miroslav Micko, Sergio Milliet, Marc Sandoz, Gino Severini, James Johnson Sweeney, Albert Tucker, Lionello Venturi, Eduardo Vernazza, Marcel Zohar, Paul Fierens ve Herbert Read gibi isimler yer almıştır. Uluslararası Sanat Eleştirmenleri Derneği (AICA), UNESCO'da düzenlenen bu iki uluslararası kongreyi takiben 1950'de kurulmuş, 1951 yllında ise sivil toplum kuruluşu konumunu kazanmıştır³.

AICA'nın 1953'de Dublin'de gerçekleşen toplantısına katılan Türkiye üyeleri Suut Kemal Yetkin ve Nurullah Berk, bir sonraki toplantının Türkiye'de yapılmasını önermişler, Yetkin'in "doğu sanatının batı sanatı üzerine tesiri” şeklindeki tema önerisi kabul görmüş ve kongre tarihi olarak 1954 yllının Eylül ayı olarak belirlenmiştir. Doğu ve batı sanatlarının tarihsel ilişkileri üzerinde duran Yetkin ve Berk, İstanbul kongresi oturumlarından birinin başlı̆̆ının "Doğu ve Batı Sanatı" olarak belirlenmesini sağlamışlardır (Yetkin, $1954: 3$ ).

Bilge Karasu kongreyi yakından takip etmiş, sunulan bildirilerin içeriğini Forum dergisine yazdığı "Sanat Eleştiricilerinin 5. Kongresi" başlıklı yazısında özetlemiştir. Yazarın aktarımına göre kongrede "Celal Esat Arseven Türk sanatının gerektiği ölçüde tanınmadığından yakınmış, Suut Kemal Yetkin, batı sanatını çeşitli yollardan etkilemiş olan İslam sanatının, bugünün batı sanatçlarını hala çekmekte, bugünkü kaygılarına uygun düşmekte olduğundan söz açmış, Bülent Ecevit doğu sanatı ile çağdaş sanatta perspektifin bozulması olayını inceleyerek ilgi çekici birtakım sonuçlara varmıştır" (Karasu, 1954e : 15).

Söz konusu kongrenin İstanbul'da düzenlenmesi vesilesiyle Yapı ve Kredi Bankası'nın düzenlediği “İş ve İstihsal” konulu resim yarışması için Lionello Venturi, Herbert Read ve Paul Fierens gibi isimlerle uluslararası bir jüri oluşturulmuştur. Ancak jürinin kararı figüratif, non-figüratif tartışmalarını körüklemiş, akademi eğitimine ve eğitmenlerine duyulan güveni sarsmıştır. Zira seçici kurul, yarışmaya katılan 38 resmi sergilenmeye değer bulmuş, 10’unu ödüllendirmiş ve birinciliği o güne dek sanat ortamında pek aktif olmayan, akademi eğitimi almamış Aliye Berger’in soyut anlatımlı eserine vermiştir. Jürinin bu kararı akademili bazı hocalar tarafından hoşnutsuzlukla karşılanmış, basında çıkan yazılarında Bedri Rahmi Eyüboğlu ve Cemal Tollu gibi ressamlar sonuçları oldukça sert bir dille eleştirmiştir (Yasa Yaman, 1996a: 34-36)4. Öte yandan Zeynep Yasa Yaman’a göre yarışmaya katılan tek "soyut" anlatımlı resmin sahibi Aliye Berger, farkında olmadan çevresinde bir firtına koparmış, çoğunluğunu d Grubu üyelerinin oluşturduğu ve Akademi yönetimini elinde tutarak sanatı güdümledikleri savlanan, Cumhuriyet’in bu ilk kuşak sanatçllarına, onların kübist, konstrüktivist, fütürist anlayışına eleştirel yaklaşımlar da başlamıştır (Yasa Yaman, 1998 : 106).

\footnotetext{
3 AICA hakkında daha detaylı bilgi için kuruluşun resmi web sayfasına başvurulabilir : http://aicaturkey.org/aicainternational-history

Ayrıntılı bilgi için bkz. Kaygısız Ergin, 2000 : 98 - 104.
}

Adres

Kırklareli Üniversitesi, Fen Edebiyat Fakültesi, Türk Dili ve Edebiyatı Bölümü, Kayalı Kampüsü-Kırklareli/TÜRKIYE e-posta: editor@rumelide.com
Address

Kirklareli University, Faculty of Arts and Sciences, Department of

Turkish Language and Literature, Kayalı Campus-Kırklareli/TURKEY e-mail: editor@rumelide.com 


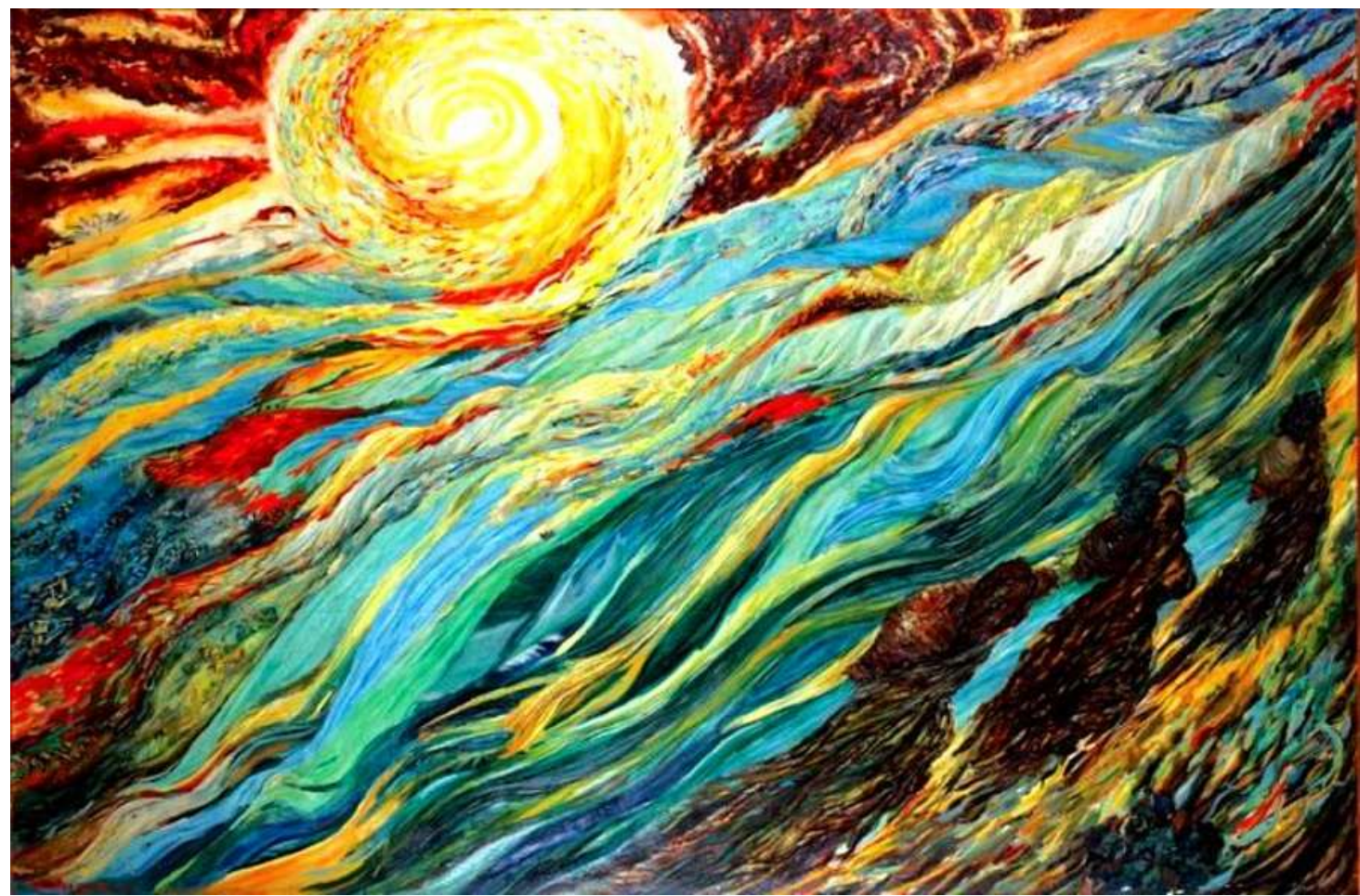

Tablo 3: Aliye Berger, "Güneşin Doğuşu” 1954, tuval üzerine yağlıboya, 200x300 cm., Yapı Kredi Bankası A.Ş. Koleksiyonu (Germaner, S. \& Koçak, O. vd., 2008 : s. 45)

Karasu, “İş ve İstihsal” yarışmasını önceki yazılarında da gördüğümüz gibi üslup ve yenilik kavramları çerçevesinde, jüriye ve dolayısıyla birincilik ödülü alan Aliye Berger’e yöneltilen eleştirileri göz önünde bulundurarak değerlendirmiştir:

“(...) Ressamların çoğu 25-30 yıl önce yapılan resimler havasında eserler vermişler. Bir kaçı, bunu kendi üsluplarına - kendi üslupları böyle konular içinde gelişmiş olanlar az değil- yedirdiler (...) Bir tanesi, eline firçayı almış, bir üslup yaratmıştır : Yarışmanın birincisi, Aliye Berger (...) Berger, konuyu doğrudan doğruya işlememiştir. (Bu bakımdan, resminin üzerine "mahallinde bizzat müşahede edilerek” yapıldığını yazan ressamın karşıtıdır) (...) Ressam, resim öğretimiyle yetişmiş bir ressam değildir. Teknik bakımından zayıftır. Ama bütün bunlar sayıldıktan sonra da ortada kalan resim, bir ressam kişiliği gösteren bir resim. Boyalarının hareketi, bir çeşit izlenimciliği, güçlü duygululuğu ile dünyasını bir göz dünyası haline sokmuş olan bir kimse çıkıyor karşımıza. Resmin ötekilerden bambaşka bir resim olması, eleme kurulunun seçmesine etki etmiş olabilir. Ama ne denirse densin, bu başkalık boş bir başkalık değil; serginin öteki resimleri arasında gerçekten bir değer taşıyan bu resim ayrıca bizde hiç rastlanmayan bir resim üslubunun öncüsü olarak da görülmelidir” (Karasu, 1954e : 17).

\section{Sonuç}

Bilge Karasu, 1952 yllından itibaren hem ilk öyküleri ve şiirleri hem de edebiyat eleştirileriyle Seçilmiş Hikayeler Dergisi, Küçük Dergi, Yeditepe, Akis, Vatan Gazetesi, Yenilik, Yücel, Pazar Postası gibi yayınlarda yer almıştır. Yazarın 1963'te Forum yayınları tarafından yayımlanan ilk kitabı Troya'da Ölüm Vardı içinde yer alan öykülerin bir kısmı 1950’ler süresince Yenilik, Yücel ve Forum dergilerinde basılmıştır5.

5 Ayrıntılı Bilge Karasu kaynakçası için bkz. İleri, 2007 : 257 - 266.

Adres

Kırklareli Üniversitesi, Fen Edebiyat Fakültesi, Türk Dili ve Edebivat Bölümü, Kayalı Kampüsü-Kırklareli/TÜRKiYE e-posta: editor@rumelide.com
Turkish Language and Literature, Kayalı Campus-Kırklareli/TURKEY e-mail: editor@rumelide.com 
Karasu'nun Forum dergisinde toplam 57 yazısı yayımlanmıştır. Bu yazıların 36 tanesi resim, heykel, seramik ve sanat etkinlikleri üzerine yazılmıştır. Dolayısıyla yazarın en uzun soluklu ve yoğun dergi yazarlığı deneyiminin Forum'da gerçekleştiği görülmektedir. Metin boyunca özetlenen konuların yanı sıra kişisel sergiler hakkında da yazan Karasu, Hayrullah Tiner, Ali Teoman Germaner, Abdurrahman Öztoprak, Sadi Diren, Şükriye Dikmen, Naim Fakihoğlu, Lamar Dodd, Kayıhan Keskinok, Vildan Aktutay Tatlıgil, Jerfi Kayıhan, Tektaş Ağaoğlu, Ruhi, Ferruh Başağa ve Bülent Arel gibi sanatçların üretimlerini eleştirilerine taşımıştır.

Yazarın sanat eleştirilerinde en sık kullandığı kavram “istif”tir. Karasu bu kavramı figüratif resimlerde kompozisyonu oluşturan elementlerin bütünlüğünü, soyut resimlerde ise renk ve çizgi düzenlerini vurgulamak için kullanmaktadır. Bu bağlamda istif bakımından yalın, üslup inceliği, zarifliği gibi ifadeler sıklıkla karşımıza çımmaktadır (Karasu, 1954a : 18, 1954b : 15, 1954c : 18, 1954g : 21, 1955a : 20). Çizgisel değerler barındıran yapıtları değerlendirirken ise çizgiyle sınırlanan, incelmiş çizgiler, biçim sınırları, nakış düzeni içinde gibi birtakım kalıp ifadeleri kullanmaktadır (Karasu, 1954a : 18, 1954e : 18-19, 1955e : 22-23).

Karasu'nun eleştirilerinde önemli yer tutan diğer kavram ise "renk"tir. Kaleme aldığı pek çok yazıda renklendirme gücü, renklerin koyulaşıp kararması, hafiflemiş renkler, söndürülmüş renkler, renklerin uyumu, güçlü ama sağır renkler, parlak lekeler, açık-koyu dengesi gibi ifadeleri sik sik kullanmıştır (Karasu, 1954a : 18, 1954c : 18-19, 1955e : 22-23, 1957b : 22-23).

Yazarın izlediği sergilerdeki bazı yapıtları, sanat tarihinin farklı dönemlerinden sanatçı, teknik, akım/ekollerle de ilişkilendirdiği görülmektedir. Bu ilişkiyi kurarken yapıtın kendisinde uyandırdığı izlenimlerden yola çıkar, dolayısıyla ele aldığı sanatçının çağdaşı olmayan pek çok kavram metinlerinde bir araya gelir. Örneğin Tektaş Ağaoğlu'nun resimlerini yüzlerce yıllık bir zaman diliminden seçtiği bazı sanatçı ve akımlarla birlikte okur. Karasu'ya göre "ressamın ağır basan "romantique" yönü gerek renklerin seçilişinde, gerekse de yarattığı "hava"da belirmiş, 3 sayılı resim Rembrandt'ın "Yüzülmüş Sığır" ını, sarı-kara küçük bir resim ise geçen yüzyılın ilk yarısında yapılan kitap "gravüre”lerini, 16 sayılı resim "Impressioniste"leri, 10 sayll kırmızı resim ise "romantique" resimlerin değerlerini" anımsatmaktadır (Karasu, 1957e : 23). D.T.C. Fakültesinde gerçekleştirilen Ankara Koleji Resim Sergisi'nde gördüğü eserleri "Japon resmi, Hint heykeli, çağdaş Avrupa resmi, hepsine bakılmış, hepsinden etkilenilmiş, Klee ${ }^{6}$ ve Mondrian7 etkisi kuvvetli” sözleriyle yorumlar (Karasu, 1954d : 17). Kayıhan Keskinok'un "Klee'den etkilendiğini, bilmeden Delaunay'e ${ }^{8}$ yakın bir anlayışla resim yaptığını" ifade eder (Karasu, 1956d : 22). Bülent Arel'in 1959 yllındaki sergisinin ardından ise sanatçının “Calder'in9 açtığı bir yolda ilerlediğini, bu sergisinde Gabo ${ }^{10}$ ile Pevsner'in ${ }^{11}$ yolunda yürüdüğünü” dile getirir (Karasu, 1959d : 19-20). Ali Teoman Germaner'in heykelleri "Bizans kökenlerini”, resimleri ise "ilkellerin mağara resimlerini” anımsatmaktadır (Karasu, 1954b : 15). Benzer biçimde, 1955 yılında gördüğü Şükriye Dikmen sergisinde de pek çok farklı üslubun etkilerini gözlemler ve yazısına aktarır:

“Paris’te uzun zaman resme çalışan bayan Dikmen’in resimlerini ustası Léger ${ }^{12}$ etkilemiştir denemez. Bu resimlerde görülen yalınlık, uzay bakımından çoğunun belirsiz bir boşluk içinde oluşu, biçimlerin dümdüz, hareketin doğrudan doğruya bir yüzey hareketi olması, Léger'den uzak kalan özellikler.

Paul Klee (1879 - 1949) Alman kökenli İsviçreli ressam.

Piet Mondrian (1872 - 1944) Hollandalı ressam, De Stijl sanat hareketi ve oluşumunun destekçisi.

Robert Delaunay (1885 - 1941) Orphism sanat hareketinin kurucularından Fransız ressam.

Alexander Calder (1898 - 1976) Amerikalı heykeltıraş ve ressam.

Naum Gabo (1890 - 1977) Rus kökenli konstrüktivist heykeltıras.

Antoine Pevsner (1884 - 1962) Rus kökenli konstrüktivist heykeltıraş.

Fernard Léger (1881-1955) 20. yüzyıl Paris Ekolü sanatçılarından. 1945 sonrası Paris’e giden pek çok Türkiyeli sanatçının hocasi olmuştur. 
Buna karşllık daha eski çıplaklarıyla portrelerinde Gauguin'in ${ }^{13}$, Modigliani'nin ${ }^{14}$, daha yeni manzaralarında doğu minyatürlerinin, Japonların, birtakım Avrupalı ressamların üslup yahut hava bakımından etkileri görülüyor" (Karasu, 1955a : 20).

Cumhuriyet döneminden 1950'lere uzana süreçte Türkiye'de sanat eleştirisinin temel sorunsalları Osmanlı öncesi kaynaklardan yararlanma, batı öykünmeciliğinden kurtulma, sanata devrimin hizmetinde ideolojik bir anlam yüklenmesi, halk sanatı kaynakları ile ilişki kurma ve sanatın politik bir kimliğe kavuşturulması olmuştur. Öte yandan 1937 - 1950 yılları arasındaki eleştiri metinlerinde karşıtı ve kapsamı belirsiz güzel, muvaffak, yeknesak gibi öznel ifadelerin sıklıkla kullanıldığı görülmektedir. Bu süreçte kişisel beğeninin ötesinde üslup, renk ve desen gibi kavramlar belirginleşmeye başlamış, resim eleştirisinin temel unsurları haline gelmiştir. Ancak soyut, yapısal ve geometrik gibi kavramlar 1950'lere gelindiğinde eleştiri dağarcığına girmiş, "soyut/ mücerret/ abstre", "non-figüratif/ figürsüz" en önemli tartışma konuları haline gelmiştir (Duben 2007 : 215; Yasa Yaman, 1996b : 32 - 33 ; Yasa Yaman, 1998 : 101). Bilge Karasu'nun da benzer şekilde, sanat yapıtını ağırlıklı olarak biçimsel özellikleri yönünden ele aldığı, deneyim kazandıkça ise farklı sanat tarihsel referanslarla metinlerini zenginleştirdiği görülmektedir. Öte yandan bazı sanat eleştirilerine attığı Etkiler-Duygular, Deniz Diplerinde Başlyan Derin, Kaygısız, Korkusuz, Boşluklar ve Yabancllk Elginlik gibi başlıkların, yazarın bu yıllarda olgunlaşmaya başlayan öykücü kimliğinin izlerini taşıdı̆̆ı düşünülebilir.

Karasu 1950'lerin sonundan itibaren deneme, öykü ve çeviri metinlere ağırlık vermiştir. Ancak plastik sanatlarla bağını asla koparmayan yazarın 1973 yılında Ertuğrul Oğuz Fırat ve Turan Erol'un resimleri üzerine kaleme aldığı yazıları Sanat dergisinde yayımlanmıştır ${ }^{15}$. Uzun Sürmüş Bir Günün Akşamı (1970) kitabına ise, Karasu'nun sanat tarihine ilgisini ispatlar şekilde, Bizans İmparatorluğu'nda ikonaların tahrip edildiği ikonoklazm dönemi fon teşkil etmektedir.

\section{Kaynakça}

Akkoyunlu Ersöz, B. ve Bahar, T (Ed.). (2011). İhsan Cemal Karaburçak. İstanbul : Pera Müzesi.

Anonim. (1952). Young Man of Modern Art. Life Magazine, 12 Mayss, 32. cilt, 19 : s. 85-87.

Berk, N. (1952). Sanat Bahisleri : Devlet Resim ve Heykel Sergisi. Zafer, 15 Nisan : s. 2.

Çakmak, D. (2007). Forum Dergisi : 1954 - 1960 (Doktora tezi). Ankara Üniversitesi Sosyal Bilimler Enstitüsü: Ankara.

Dede, K. (2015). Forum Dergisi. Türkiye’nin 1950’li Yilları (Haz. Mete Kaan Kaynar). İstanbul: İletişim, s. $451-464$.

Duben, İ. (2007). Türk Resmi ve Eleştirisi (1880 - 1950). İstanbul : Bilgi Üniversitesi.

Ecevit, B. (1954). Hasan Kaptan Adında Bir Ressam. Yeni Ulus, 9 Nisan : s. 3.

Elvan Erturan, N. (2001). Türk Plastik Sanatlarında Otodidakt ve Naif Sanat, Çocuk Yaratıcılı̆g (19501960). (Yüksek lisans tezi). Hacettepe Üniversitesi Sosyal Bilimler Enstitüsü : Ankara.

Germaner, S., Koçak, O. vd. (Ed.). (2008). Modern ve Ötesi : 1950 - 20oo. İstanbul : Bilgi Üniversitesi. Güran, R. (1958). Cemil Eren’in Sergisi. Yeditepe, 124 : s. 4.

İleri, C. (2007). Yazının da Yırtılıverdiği Yer, Bir Bilge Karasu Okuması. İstanbul : Metis.

Kahramankaptan, Ş. (1998). İsmet İnönü ve Harika Çocuklar. Ankara : Ümit.

Karasu, B. (1954a). Helikon'da Hayrettin Timer'in Sergisi - Hasan Kaptan Sergisi Forum. 2 : s. 18.

Paul Gauguin (1848 - 1903) Post-İzlenimci ressam.

Amedeo Clemente Modigliani (1884 - 1920) İtalyan ressam ve heykeltıraş.

Söz konusu yazılar, yazarın Kısmet Büfesi (Metis Yayınları, 2004) başlıklı kitabına dâhil edilmiştir. 
Karasu, B. (1954b). Helikon'da Aloş'un Sergisi - XV. Devlet Resim ve Heykel Sergisi. Forum, 3 : s. 15.

Karasu, B. (1954c). Helikon'da Abdurrahman Öztoprak'ın Sergisi. Forum, 4 : s. 18-19.

Karasu, B. (1954d). D.T.C. Fakültesinde Ankara Kolleji Resim Sergisi. Forum, 5 : s. 17.

Karasu, B. (1954e). Sanat Eleştiricilerinin V.Kongresi - İstanbulda İki Sergi. Forum, 13 : 15 - 17.

Karasu, B. (1954f). Sadi Diren'in Sergisi. Forum, 15 : s. 17-18.

Karasu, B. (1954g). Japon Resimleri Sergisi. Forum, 18 : s. 21.

Karasu, B. (1955a). Şükriye Dikmen'in Sergisi. Forum, 20 : s.20.

Karasu, B. (1955b). İki Sergi. Forum, 25 : s.19.

Karasu, B. (1955c). Fakihoğlu. Forum, 26 : s.20.

Karasu, B. (1955d). Üsluplar Üzerine (G.A. imzasıyla). Forum, 22 : s.21-22.

Karasu, B. (1955e). Etkiler-Duygular. Forum, 23 : s.22-23

Karasu, B. (1956a). Helikon Sergisi (G.A. imzasiyla). Forum, 48 : s. 21.

Karasu, B. (1956b). L. Dodd (G.A. imzasiyla). Forum, 49 : s.28.

Karasu, B. (1956c). Devlet Resim Sergisi (G.A. imzasiyla). Forum, 51 : s. 28-29.

Karasu, B. (1956d). Tutuma Övgü. Forum, 61 : s. 22.

Karasu, B. (1957a). Bir Sergi (G.A. imzasıyla). Forum, 67 : s.23.

Karasu, B. (1957b). Deniz Diplerinde Başliyan Derin. Forum, 68 : s. 22-23.

Karasu, B. (1957c). Kayıhan (G.A. imzasiyla). Forum, 71 : s. 23-24.

Karasu, B. (1957d). Kaygısız, Korkusuz, Boşluklar. Forum, 72 : s. 22-23.

Karasu, B. (1957e). Soyut Resimler. Forum, 73 : s. 23.

Karasu, B. (1957f). Sergiler. Forum, 77 : s. 23-24.

Karasu, B. (1957g). Çağdaş Türk Kültürünü Tanıtma Haftası. Forum, 89 : s. 22-23.

Karasu, B. (1957h). Yabancllı Elginlik. Forum, 90 : s. 21-22.

Karasu, B. (1958a). Eren. Forum, 93 : s.24.

Karasu, B. (1958b). İyem. Forum, 96 : s. 18.

Karasu, B. (1958c). Renkli Renkli Taşlar. Forum, 99 : s. 23.

Karasu, B. (1958d). Sergi Bolluğunda Devlet Sergisi. Forum, 100 : s. 22-23.

Karasu, B. (1958e). İki Olay. Forum, 101 : s. 19-20.

Karasu, B. (1959a). A.B.D. Resim Tarihinde Bir Gezinti. Forum, 112 : s. 22-23.

Karasu, B. (1959b). Yeni Eren. Forum, 115 : s. 22.

Karasu, B. (1959c). Ağaoğlu. Forum, 116 : s. 19.

Karasu, B. (1959d). Arel. Forum, 118 : s. 19-20.

Kaygısız Ergin, A. (2000). 1950-196o Ylllarl Arasında Türk Resim Sanatında Konu Yönelimi (Yüksek lisans tezi). Hacettepe Üniversitesi Sosyal Bilimler Enstitüsü : Ankara.

Yağcığlu, H. (1954). Panorama. Kaynak, 94 : s.156-157.

Yasa-Yaman, Z. (1996a). Modernizmin Siyasal/İdeolojik Söylemi Olarak Resimde Köylü/Çiftçi İzleği. Türkiye'de Sanat, 22 : s. 29-37.

Yasa-Yaman, Z. (1996b). Cumhuriyet Dönemi Resim Eleştirisinin Kaynakları. Türkiye'de Sanat, 24 : s.32- 38 . 
Yasa-Yaman, Z. (1998). 1950'li Yılların Sanatsal Ortamı ve "Temsil” Sorunu. Toplum ve Bilim, 79 : s. 94 $-137$.

Yetkin, S. K. (1954). Sanat Tenkitçileri Kongresi. Yeditepe, 53 : s. 3.

Zürcher, E. J. (2006). Modernleşen Türkiye’nin Tarihi. İstanbul : İletişim. 